\title{
Ipuin-moldaketa herri-hizkerara egokitzeko eta modu esanguratsuan kontatzeko markaketa: Ahozko komunikazioa lantzen eta aztertzen Haur Hezkuntzako gelan
}

\author{
Story adjustments to bizkaian and a marking proposal for significant \\ storytelling: Practicing and analyzing oral communication in an early \\ education classroom
}

\author{
Udane Beaskoetxea*, Mikel Iruskieta \\ Bilboko Hezkuntza Fakultatea \\ $\mathrm{UPV} / \mathrm{EHU}$
}

\begin{abstract}
LABURPENA: Lan honetan Martin Txiki eta Basajaunak ipuinaren irakurketa ozen esanguratsuak talde zehatz bateko haurren hizkuntza- eta komunikazio-gaitasunean izan duen eragin zuzena aztertu da, beren beregi diseinatutako esku-hartze eta ikerketa baten bidez. Zehatzago, ipuina bizkaierara moldatu da eta Mungiako Legarda HLHI ikastetxeko Haur Hezkuntzako 4 urteko gela batean irakurri da, horrek haurrek duten euskalkiaren ezagutzan eta egiten duten erabileran duen eragina aztertzeko. Eskuhartzea egiteko lan moldea konstruktibismoan oinarritu da. Beraz, haurrek euskalkiaren zein jabekuntza duten zehazteko aurretiazko jarduerak egin dira. Ondoren, ipuin horren irakurketa esanguratsua burutu da euskara batuan eta mendebaldeko euskalkian, horren osteko jardueren bidez, euskalkian irakurtzeak haur ezberdinen ahozko komunikazio-gaitasunean izan duen eragina neurtzeko. Orokorrean ondorioztatu da euskalkian egindako irakurketak gaitasun hori osotu duela, nahiz eta euren ama-hizkuntzaren arabera emaitza ezberdinak eman diren.
\end{abstract}

GAKO-HITZAK: ahozko komunikazio-gaitasuna, irakurketa esanguratsua, konstruktibismoa, ipuina, euskalkia

ABSTRACT: In this work, we designed an intervention and investigation to analyze the direct effects in the development of children's linguistic and communicative skills when we read aloud the story called Martin Txiki eta Basajaunak. In particular, we modified the story to the occidental dialect and read it aloud in one 4 years-old class of pre-school in the college Legarda of Mungia, in order to analyze the effects in children's knowledge and use of the dialect. The methodology used in the intervention was based on constructivism. Therefore, we conducted previous activities which would help us consider children's knowledge about this dialect. Afterwards, the story was read aloud both in batua (unified Basque) and in the occidental dialect. Finally, subsequent activities were carried out in order to weigh the consequences of using dialect in children's oral communicative skills. In general, children's have developed communication skills in the occidental dialect, even if the results changed depending on their mother language.

KEYWORDS: oral communicative skills, meaningful reading, constructivism, story, dialect

* Harremanetan jartzeko / Corresponding author: Udane Beaskoetxea Elezgarai. UPV/EHU. Bilboko Hezkuntza Fakultatea. Sarriena auzoa, Z/G. E-48940 - Leioa - udabea@gmail.com

Nola aipatu / How to cite: Beaskoetxea, Udane; Iruskieta, Mikel. (2019). «puin-moldaketa herri-hizkerara egokitzeko eta modu esanguratsuan kontatzeko markaketa: Ahozko komunikazioa lantzen eta aztertzen Haur Hezkuntzako gelan»; Tantak, 31(1), 53-80. (https://doi.org/10.1387/tantak.20149).

Jasotze-data: 2018/09/19; Onartze-data: 2018/10/22

ISSN 0214-9753 - elSSN 2444-3581 / (c) 2019 UPV/EHU

(c) (i) Obra hau Creative Commons Atribución 4.0 Internacional-en lizentziapean dago 


\section{SARRERA}

Gaur egun, salbuespenak-salbuespen ${ }^{1}$, euskara batuan daude Euskal Herriko ikastetxe eta ikastoletan erabiltzen diren material didaktikoa eta literatura-irakurgaiak, baita Bizkaian erabiltzen direnak ere. Euskara hori da ahozkoaren (eta idatzizkoaren) ardatz hezkuntza-sisteman eta baita Haur Hezkuntzan (HH) ere. Euskara batua sortu zenetik, ahozko hizkuntza- eta komunikazio-gaitasunen lanketa euskara horretara zabaltzeaz gain tokiko hizkuntzetara, hau da, euskalkietara, hedatzearen aldeko ahalegin teorikoak egin dira (Maia eta Larrea, 2008).

Maiaren eta Larrearen (2008) aburuz, euskara batuaren eta euskalkiaren arteko kontrakotasun fase baten ostean, gaur egun, bien arteko osagarritasunaren aldeko ideia gailendu da, biek komunikazio-gaitasunaren garapenean laguntzen baitute. Osagarritasun hori eskolan ere islatu beharra dago (HHtik hasita). Hala adierazi zuten Euskaltzaindiak eta Eusko Jaurlaritzak 1982ko adierazpen banatan ${ }^{2}$. Nazioartean ere hizkuntza-barietateak onartzen dira; alde batetik, estandarra ulermenaren berme gisa eta, bestetik, aldarazpenak komunitateen nortasunaren adierazpen gisa (Crystal, 2003).

237/2015 Dekretuak, abenduaren 22koak, Haur Hezkuntzako curriculuma zehaztu eta Euskal Autonomia Erkidegoan ezartzekoak berak ere horren alde egin du. Curriculumeko hasierako xedapenetan haurrek familiatik dakarten hizkuntzari arreta berezia jartzeko beharra aipatzen da, hizkuntza-konpetentzia guztiak biltzen dituen hizkuntza-multzoa garatzeko helburua dagoela adieraziz. Familiatik dakarten hizkuntza horien artean, euskalkia ala tokian tokiko herri-hizkera barneratuta dagoela ulertzen dugu, are gehiago, nortasunaren eraikuntzaren eta komunikazioaren eta adierazpenaren eremuan, HHko bigarren zikloko edukien artean beren beregi aurreikusten denean «hizkuntzak eta dialektoak erabiltzeko interesa izatea eta haiek begirunez begiratzea». Eduki hori indar handiagoz landu beharko da, ingurunearen baldintza soziolinguistikoek hala eskatzen dutenean (9. artikulua).

Aurreko guztiari gehitu behar zaio komeni dela eskola ingurunean (ingurunetzat ulertuta, familia, herria eta eskualdea) txertatua egotea eta, beraz, inguru horretako errealitate soziolinguistikoa ere kontuan hartzea. Maiak eta Larreak (2008) diote, ikastetxeko eta ikasgelako hizkuntza-politika euskalkiduna ezartzeko erabakigarriak direla, alde batetik, eskualdean euskara bizkorra izatea eta, bestetik, bertan euskalkia ezagutzea. Horren ondorio zuzena da, ingurune erdaldunean dauden kasuetan, ikastetxeak euskara batuaren ${ }^{3}$ aldeko hautua egitea. Kontrara, ingurunea euskalkiduna

1 Salbuespenak ere badaude, eskola eta ikastoletan bizkaiera edota herriko euskalkia erabili izan da eta erabiltzen da.

2 1982ko urriaren 22ko Euskararen erabilera Bizkaiko irakaskuntzan izeneko adierazpena eta 1982ko Hezkuntza, Unibertsitate eta Ikerketa Sailaren adierazpena, hurrenez hurren.

${ }^{3}$ Erregistro formala eta ez-formala lantzea komeni da aukera honen kasuan. 
Ipuin-moldaketa herri-hizkerara egokitzeko eta modu esanguratsuan...

den kasuetan, euskara batua eta euskalkia (biak) mantentzea da zuzenena, eta gehiago oraindik horretarako proportzio kritikoa ${ }^{4}$ betetzen denean.

Lan honen helburu orokorra da haurren ahozko hizkuntza- eta komunikazio-gaitasunaren garapenean laguntzea, horretarako Haur Hezkuntzako 4 urteko gela batean ezarriko den eta euskalkiari arreta berezia eskainiko dion esku-hartzea diseinatuz. Lan hau Mungiako Legarda HLHI ikastetxean egin da; bertan Mungialdeak berezko duen Bizkaiko Ipar-Sartaldeko euskara hitz egiten da. Helburu hori betetzeko, haurrei Martin Txiki eta Basajaunak ipuina modu esanguratsuan irakurriko zaie ${ }^{5}$, euskara batuan lehenengo eta eskualdeko euskalkian gero ${ }^{6}$. Hortaz, helburu orokor horrek azpi-helburu hirukoitza hartzen du barnean:

a) Ipuinen irakurketa esanguratsuak haurren ahozko komunikazio-gaitasunaren garapenerako baliagarritasunik duen aztertzea.

b) Ahozko komunikazio-gaitasun osoagoa garatzeko euskalkiak ${ }^{7}$ haurrengan baliagarritasunik duen aztertzea.

c) Ipuinetan ahozkoa ez den komunikazioa prestatzeko azaleko irizpideak ematea irakaslegaiei ipuin zehatz batean.

Horrez gain, ipuinaren irakurketaz gain aurretiaz eta ondoren egiteko diseinatu diren jarduerekin osatu da ipuin-tailerra ${ }^{8}$, haurren garapenean laguntzeko eta ahalik eta kalitaterik oneneko datuak biltzeko.

Esku-hartze didaktiko honetan lortuko diren emaitzen aurrean dauden hipotesiak ondokoak dira:

a) Ipuinen irakurketa esanguratsuak haurren ahozko komunikazio-gaitasuneko forma batzuk garatuko dituzte bere osotasunean, haurren ama-hizkuntza edozein dela ere $\left(\mathrm{H}_{1}\right)$.

b) Bizkaierara moldatuta dagoen ipuinaren irakurketa esanguratsuak haurren ahozko komunikazio-gaitasuna osatuko du eta haurrek amahizkuntza zein den kontuan hartuta emaitza ezberdinak erakutsiko dituzte $\left(\mathrm{H}_{2}\right)$ :

\footnotetext{
${ }^{4}$ Maiarentzat eta Larrearentzat (2008) 3 eta 6 urte bitarteko haurren ikasgelen kasuan ikasleen \% 20-40 euskaldunak direnean proportzio kritikoa dagoela esan daiteke. Hortik aurrera euskalkia izan daiteke ikastetxean erabiltzen den hizkuntza eremu curricularrean. Baina tamalez ez da eskoletan proposamen hori arnas guneetan ere betetzen.

${ }^{5}$ Horretarako, geroago azalduko diren markaketa-sistema eta keinuez baliatuz.

${ }^{6}$ Horretarako, jatorrizko ipuina bizkaierara eta zehatzago Mungiako herri-hizkerara moldatu da.

7 Aurrerantzean euskalkia edo bizkaiera aipatzen direnean Mungiako herri-hizkerari egingo diogu erreferentzia eta hizkera hori aztertu duten adituentzat erabilienak diren egiturak eta hitzak direla adieraziko dugu, nahiz eta jakin hitz horiek guztiak edo gehienak euskara batuko hiztegikoak direla edo bizkaierako beste euskalki batzuetan ez direla erabiltzen.

${ }^{8}$ Quitok (2005) dio tailerra espezializatutako lekua dela eta, bertan, hausnartutako jarduerak egiten direla.
} 
- Euskalkidun haurrek tokian tokiko hizkerak berezko dituen hiztegi eta egitura batzuk erabiliko dituzte hasieratik $\left(\mathrm{H}_{2.1}\right)$.

- Euskalkidun haurrek tokian tokiko hizkerak berezko dituen hiztegi eta egitura berriak ikasi dituztela erakutsiko dute irakurketaren osteko jardueretan $\left(\mathrm{H}_{2.2}\right)$.

- Ama-hizkuntza euskara batua duten haurrek ez dituzte tokian tokiko hizkerak berezko dituen hiztegi eta egiturak erabiliko eskuhartzearen aurretiazko jardueretan $\left(\mathrm{H}_{2.3}\right)$.

- Ama-hizkuntza euskara batua duten haurrak azken fasera heltzen direnerako zenbait egitura erabiltzen hasiko dira $\left(\mathrm{H}_{2.4}\right)$.

- Ama-hizkuntza euskara ez duten haurrek zailtasunak izango dituzte, aurretiazko jardueretan, irudietan agertutako kontzeptu eta jarduerak izendatzeko, ez dituzte tokian tokiko hizkerak berezko dituen hiztegi eta egiturak erabiliko. Gainera, maileguak ere erabiliko dituzte $\left(\mathrm{H}_{2.5}\right)$.

- Ama-hizkuntza euskara ez duten haurrek euskalkiarekiko sena eta ezagutza indartuko dutela eta aurreko taldeak bezala, euskalkiak berezko dituen egitura eta hitzak erabiliko dituztela erakutsiko dute irakurketaren osteko jardueretan, hein txikiago batean bada ere $\left(\mathrm{H}_{2.6}\right)$.

Lan hau egiteko Haur Hezkuntzako 4 urteko gela batean Martin Txiki eta Basajaunak ipuinean oinarritutako esku-hartzeak egin dira eta 3 ikasle-talde ezberdin osatu dira hipotesiak egiaztatzen diren ikusteko. Irakurri aurretik, aurrezagutzak zehazteko eta haurrek ipuinari buruzko hipotesiak sortzeko jarduerak egingo dira eta, gero, berriz, hizkuntza arloan ikasitakoa barneratuta duten ebaluatzeko eta hizkuntza-gaitasuna elkarrizketa bidez garatzeko jarduerak egin dira. Jarduera horien guztien emaitzak jasotzeko, fitxa ezberdinak eta ikus-entzunezko euskarria duten baliabideak erabili dira, grabazioak. Horrek aukera eman digu haurrek esku-hartzearen aurretik eta ondoren zuten hizkuntza- eta komunikazio-gaitasuna alderatzeko. Ipuina euskara batuan eta bizkaieraz modu esanguratsuan irakurri da eta hori egin ahal izateko urrats guztiak deskribatu dira: ipuina kontatu aurreko esku-hartzea, ipuinaren markaketa modu esanguratsuan kontatzeko, ipuina kontatu ondorengo esku-hartzeak. Bukatzeko, azpimarratu nahi dugu sortutako materiala berrerabiliko dela hezkuntzan beste ikasle batzuei irakasteko: Martin Txiki eta Basajaunak ipuina bizkaieraz eta ipuineko irudiekin irakurri eta grabazioak batueraz eta bizkaieraz ikusi eta entzun ahal izango dituztela.

Emaitzei dagokienez, laneko helburu nagusia bete da, baina egin diren hipotesi guztiak ez dira bete; izan ere, haur guztiek, euren ama-hizkuntza edozein dela ere, euskalkiak berezko dituen egiturak dakizkite irakurri aurretik egindako jardueretan, ama-hizkuntza euskalkia ez duten haurren kasuan hein txikiagoan bada ere (hipotesietako aurreikuspenak gaindituz). Hala ere, denek ikasi dituzte euskalkiak berezko dituen egitura berriak eta 
Ipuin-moldaketa herri-hizkerara egokitzeko eta modu esanguratsuan...

euren diskurtsoan erabili dituzte hein handiagoan edo txikiagoan, taldearen arabera. Horrez gain, uste dugu hizkuntza ikasi eta komunikazio-gaitasunaren garapenean ipuinak baliagarriak izan daitezkeela esku hartze egokiak eginez gero. Nabarmentzekoa da emaitzok mugatuak direla; izan ere, eskola batean, talde txikian eta inguru soziolinguistiko zehatz batean egin den lana izan delako.

\section{ESPARRU TEORIKOA ETA KONTZEPTUALA}

Hizkuntzen Europako Erreferentzi Marko Bateratuaren arabera (González-Such, Jornet eta Bakieva, 2013) hizkuntza-gaitasuna, pertsona batek hizkuntza baten hiztegiaren, fonologiaren eta sintaxiaren inguruan duen ezagutza eta gaitasuna da. Eusko Jaurlaritzaren arabera hizkuntza-gaitasuna zeharkako gaitasuna da eta beste gaitasunak lortzeko tresna. Horrez gain, «ahozko nahiz idatzizko hizkuntzaren erabilpenari, errealitatea adierazi, interpretatu eta ulertzeko, jakintza eraikitzeko eta komunikatzeko eta pentsamoldea, emozioak eta jarrerak antolatu eta autoerregulatzeko egiten dena» da hizkuntza-gaitasuna (Eusko Jaurlaritza, 2008, 11).

Baina haurrek hizkuntzaren gramatika-arauak ikasteaz gain, hizkuntza memento eta testuinguru bakoitzari egokitzen ere ikasten dute, hau da, komunikazio-gaitasuna garatzen dute. Canalek (1983) komunikazio-gaitasun hori gaitasun gramatikalak, soziolinguistikoak, diskurtsiboak eta estrategikoak osatzen dituela adierazi zuen ${ }^{9}$ eta, beraz, komunikazio-gaitasunak hizkuntza-gaitasunak baino eremu zabalagoa hartzen du: arau gramatikalen ezagutzaz gain, onargarritasun soziala eskatzen du (kasu honetan familiarena, eskolako irakaslearena eta laguntxoena). Onargarritasun hori diskurtsoa testuinguru jakinetara egokituz lortzen da eta horretarako gaitasun estrategikoa eta balio pragmatikoa ${ }^{10}$ erabiltzea komeni da. Komunikazio-gaitasunak barneratzen dituen gaitasun horiek (hizkuntza-gaitasuna, gaitasun estrategikoa eta balio pragmatikoa) eta bakoitzak hartzen duen eremua aipatu zituen Spielmannek (2013) 1. irudian jasotako eskeman ${ }^{11}$.

\footnotetext{
9 Komunikazio-gaitasuna kontzeptuan sakontzeko Etxebarriaren eta Garayren (2013) lanera jo daiteke.

10 Balio pragmatikoa esaten zaio hizkuntza-formaren araua esplotatzeari efektu komunikatiboak lortzeko. Balio pragmatikoa onargarria bada, balio linguistikoak komunikatu ezin duen efektua deskribatzeko ere erabiltzen da (García-Arriola eta Iruskieta, 2016). Adibidez, akats edo errore bat erabil daiteke ipuinetako pertsonaiak ezaugarritzeko.

11 Canalek (1983) zehaztu zituen lehenengoz komunikazio-gaitasuna osatzen duten gaitasunak. Hala ere, Spielmannek (2013) proposatutako banaketa zehatzagoa da, 1. irudian jasotzen diren hiru eraztunak erlazionatzen eta modu sakonagoan definitzen baititu.
} 


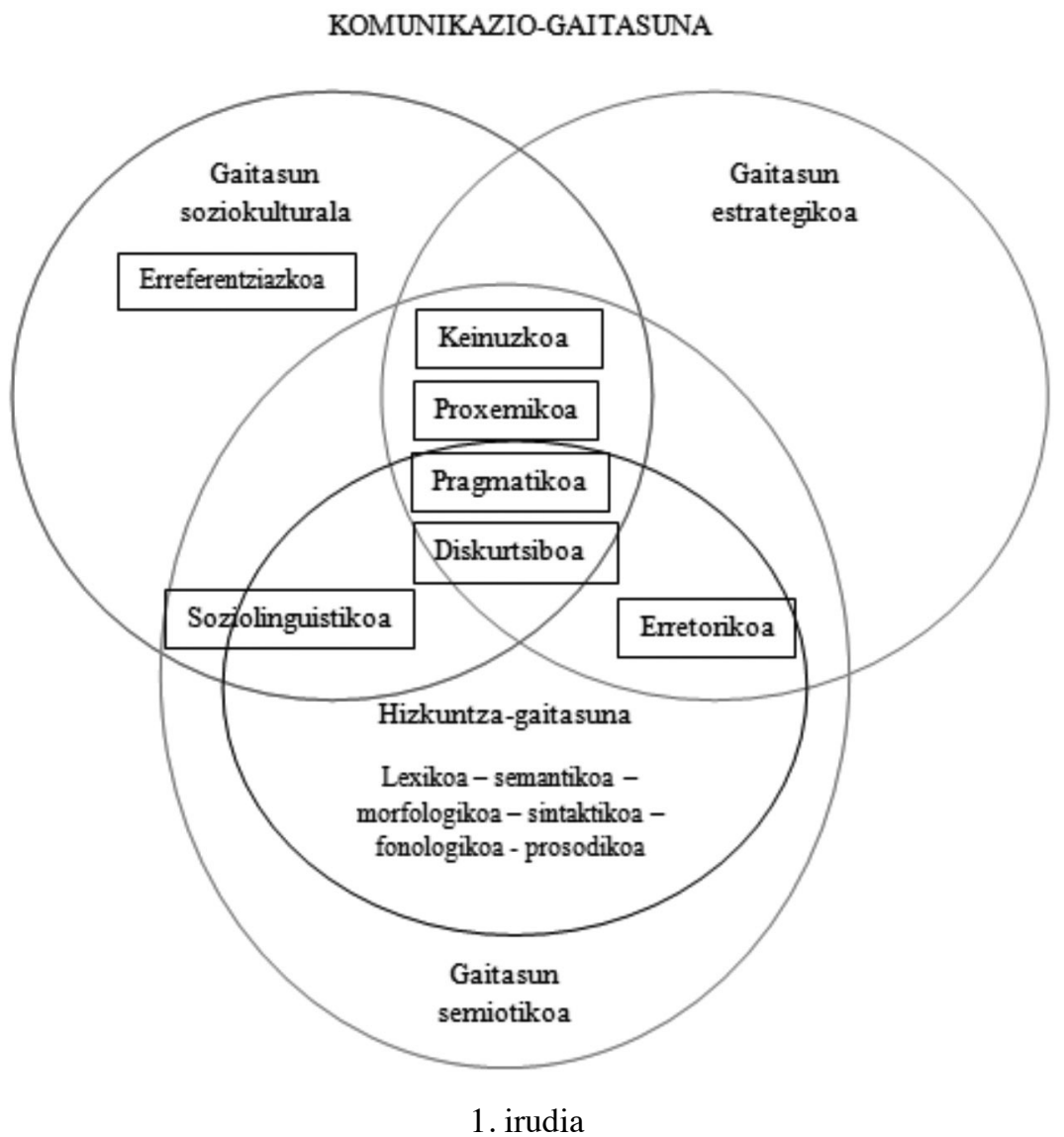

Gaitasun-komunikatiboa (Spielmann, 2013)

Aipatutako komunikazio-gaitasuna garatzeko iturri eta eredu egokiak dira literatura-irakurgaiak eta zehatzago ipuina, horretarako haurrei input esanguratsua eskaintzen dien heinean. Horrela jasotzen da 237/2015 Dekretuan, abenduaren 23koan, Haur Hezkuntzako curriculuma zehaztu eta Euskal Autonomia Erkidegoan ezartzekoan jasotako Hizkuntza- eta literatura-komunikaziorako oinarrizko konpetentzia espezifikoan .

Ipuina erabil daiteke, beraz, inguru soziolinguistiko euskalkiduna den kasuetan, hizkuntzaren bariazioa (bizkaiera) lantzeko eta haurrek horren inguruko ikaskuntza garatzeko eta komunikazio-gaitasuna osatzeko. Gaur egun, euskara batuari eta euskalkiari euren erabil-esparru bereziak bilatu nahi zaizkie, Maiaren eta Larrearen (2008) iritziz. Era berean, euskara batuak eta euskalkiak funtzio ezberdinak betetzen di- 
Ipuin-moldaketa herri-hizkerara egokitzeko eta modu esanguratsuan...

tuzte komunikazio testuinguruaren arabera eta, hortaz, bakoitza erregistro ezberdinetan erabiltzeko modukoa dela uler daiteke, norekin mintzatzen garen eta testuingurua zein den kontuan hartuta (Elordui eta Maia 2002). Euskara batua lantzea beharrezkoa da, alderdi guztietako euskaldunok elkar ulertzeko eta edozein gairi buruz hitz egiteko; eta euskalkia, aldiz, guraso eta seme-alaben arteko transmisioa sendotzeko, hizkuntza sena eta sormena indartzeko eta euskara osoagoa, zuzenagoa eta indartsuagoa eraikitzeko (Maia eta Larrea, 2008); baita lagunartean hizkera ez-formala izateko eta komunitateko izaera lantzeko. Hortaz, komeni da eskolan biak lantzea.

Hala ere, input esanguratsuak eskaintzea (kasu honetan inguru soziolinguistikoa aintzat hartuta hizkuntzaren bariazioa edo bizkaiera erabilita) lagungarri den arren ez da nahikoa; haurrak baitira bere gaitasun-komunikatiboa eraiki eta garatu behar dutenak eta eraikitzeprozesu horretan laguntzen dute metodologia konstruktibistek. Teoria konstruktibistaren arabera, haurrek ikaskuntza berria sortzen dute lehenago dituzten jakintzen gainean eta, horretarako, ezinbestekoa dute euren parte-hartze aktiboa (Maia eta Larrea, 2008). Metodologia hori hartu da oinarritzat ikasketa esanguratsua ${ }^{12}$ eraikitzen lagunduko dien ipuin-tailerra diseinatzeko. Hau da, Diazek (2016) azaldu bezala, lehenengo haurrek aurretiaz dituzten ezagutzak zeintzuk diren jakiteko jarduera batzuk prestatu dira. Ondoren, ezagutza horien gainean berriak eraikitzeko beste jarduera batzuk ere diseinatu dira. Eraikitzeprozesu osoan zehar, Segurak (2005) aipatutako aldamioa ${ }^{13}$ edo laguntza eskaini zaie haurrei; diseinatutako jarduerak erabili dira helduaren eta haurren arteko elkarrizketa elkarreragileen bidez komunikazio-gaitasuna garatzeko barne prozesua errazteko.

Komeni da laguntza hori ematea Sanchez-Canok (2001) aipatutako elkarrizketetako estrategien bidez. Hau da, komunikazio-gaitasunaren garapenean laguntzeko egokia da haurren ahozko ekoizpena indartzeko estrategiak erabiltzea. Estrategiok dira gutxieneko erantzuna eta laguntza semantikoa ematea, besteak beste, baieztapena, imitazioa, birformulazioa, zuzenketa eta kateatzea erabiliz.

Metodologia konstruktibista ardatz duen ipuin-tailerrak duen garrantzia 2. irudian laburbiltzen da. Bertan azaltzen da ipuinak ingurune soziolinguistikoan hizkuntzaren bariazioa (bizkaiera) presente dagoenean inguruneko aldaerarekin komunikazio-gaitasuna hobetzeko balio duela.

12 Maiaren eta Larrearen (2008) arabera, ikasketa esanguratsua da jakintza zaharren eta berrien arteko loturak ezartzeko aukera ematen duena.

${ }_{13}$ Seguraren (2005) arabera aldamioa irakasleak edo beste ikasleek emandako laguntza mota da. Laguntza horri esker ikasleek euren egungo gaitasunetatik nahi diren helburuak betetzeko bidea egiten dute. 


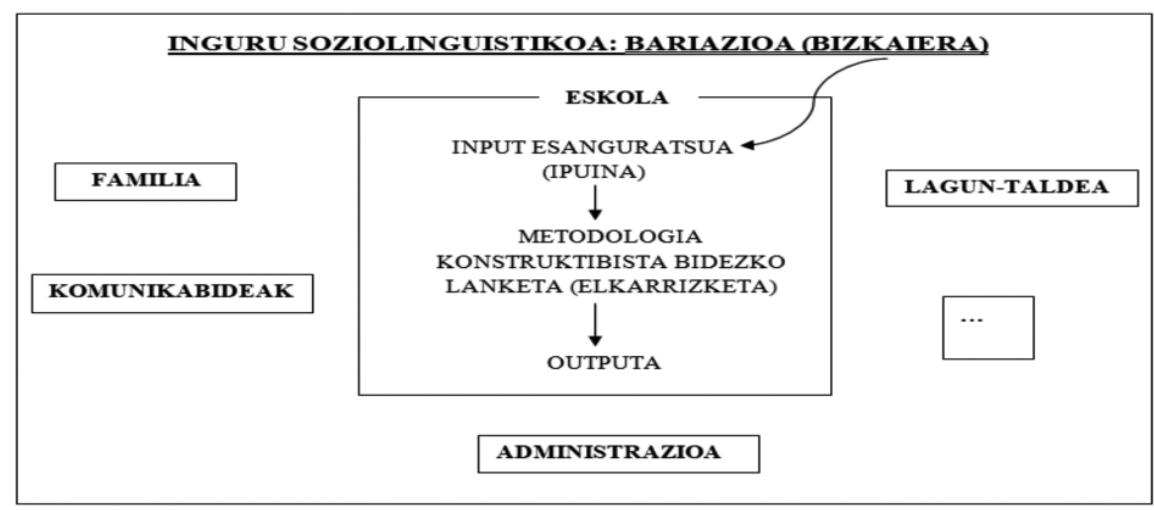

2. irudia

Haurren inguru soziolinguistikoaren eragina

\section{METODOLOGIA}

\subsection{Ipuinaren moldaketa}

Haur Hezkuntzako lau urteko gelako ikasleentzako proposamen didaktiko bat egin da ikertzeko eta erakusteko zein eragin duten irakurketa esanguratsuak eta irakurketa horretan euskalkia erabiltzeak haurren ahozko hizkuntza- eta komunikazio-gaitasunaren garapenean, haur horien ama-hizkuntza zein den kontuan hartuta.

Esku-hartzea eta ikerketa egin ahal izateko, aldez aurretik Ikastolen Elkarteak (Murua, 2010) ${ }^{14}$ argitaratutako Martin Txiki eta Basajaunak ipuina bizkaierara moldatu da. Hori da Urtxintxa Proiektuak 4 urteko haurrentzat proposatzen duen bigarren hiruhilabetekorako ipuinetako bat. Euskara batuan dago idatzita, eta ipuin hori bizkaierara moldatu da, batez ere sintaxia eta hiztegiari dagokionean. Sintaxian egindako moldaketen laburpena 1. taulan erakusten dugu. Taularen lehenengo zutabean jasotzen da moldatua izan den kategoria (adibidez, deklinabidea, aditza...), eta bigarren eta hirugarren zutabean, kategoria bakoitzari dagozkion adibideak batuaz eta bizkaieraz:

14 Bizkaierazko ipuina ikusgarri hemen: https://addi.ehu.es/bitstream/handle/10810 /31766/Martin_Txiki_eta_Basajaunak_bizkaieraz.pdf?sequence=9\&isAllowed=y 
Ipuin-moldaketa herri-hizkerara egokitzeko eta modu esanguratsuan...

1. taula

Sintaxia moldatzeko laburpen taula

\begin{tabular}{|c|c|c|}
\hline & BATUA & BIZKAIERA \\
\hline Izenordain indartuak & $\mathrm{Ni}, \mathrm{zu}, \mathrm{gu}$, hura & Neu, zeu, geu, bera ${ }^{15}$ \\
\hline Erakusleak & $\begin{array}{l}\text { Hau, hori, hura } \\
\text { Hauek, horiek, haiek }\end{array}$ & $\begin{array}{l}\text { Hau, hori, ha } \\
\text { Honeek, horreek, hareek }\end{array}$ \\
\hline Deklinabidea & $\begin{array}{l}\text {-a Garia } \\
\text { Tranpa } \\
\text { Saiakera } \\
\text {-rekin } \\
\quad \text { Batekin }\end{array}$ & $\begin{array}{l}\text {-e/-ea } \\
\text { Garie } \\
\text { Tranpea } \\
\text { Saiakerea } \\
\text {-agaz } \\
\text { Bategaz }\end{array}$ \\
\hline Postposizioak & Gabe & Barik \\
\hline \multicolumn{3}{|l|}{ Graduatzaileak } \\
\hline i) Atzizkiak & $\begin{array}{l}\text {-Txo } \\
\text { Txikitxo } \\
\text { Pixka bat } \\
\text { Urrun } \\
\text { Erraldoi }\end{array}$ & $\begin{array}{l}\text {-Txu } \\
\text { Txikitxu } \\
\text { Apurtxu } \\
\text { Asautxuau } \\
\text {-Tzar } \\
\text { Gizontzar } \\
\end{array}$ \\
\hline ii) Errepikapenak & $\begin{array}{l}\text { Bizkor } \\
\text { Zabal-zabalak }\end{array}$ & $\begin{array}{l}\text { Zuhur-zuhur } \\
\text { Nasai-nasaiek }\end{array}$ \\
\hline iii) Forma lexikalak & $\begin{array}{l}\text { Oso } \\
\text { Bikaina }\end{array}$ & $\begin{array}{l}\text { Sano }^{16} \\
\text { Itzelezko }\end{array}$ \\
\hline \multicolumn{3}{|l|}{ Aditza } \\
\hline i) Partizipio burutua & $\begin{array}{l}\text { Eman } \\
\text {-atu } \\
\text { Probatu } \\
\text { Asmatu } \\
\text { Harrapatu }\end{array}$ & $\begin{array}{ll}\text {-on } & \\
\text { Emon } \\
\text {-au } \\
\text { Probau } \\
\text { Asmau } \\
\text { Harrapau }\end{array}$ \\
\hline
\end{tabular}

15 Besteak beste $n e u$, geu eta zeu erabili dira lehenengo eta bigarren graduan eta bera hirugarren graduan, Arejitaren (2002 eta 2005) eta Zuazoren eta Goitiren (2017) arabera, izenordain indartuok erabiltzeko joera handiagoa baitago mendebaldeko euskalkietan.

16 Sano erabili da, Zuazok eta Goitik (2017) eta Mungiako ikastetxeak (2012) proposatzen duten bezala, ipuina herri-hizkerak berezko dituen ezaugarrietara ere egokitzeko. 
Udane Beaskoetxea, Mikel Iruskieta

\begin{tabular}{c|l|l}
\hline \multicolumn{2}{c}{ BATUA } \\
$\begin{array}{c}\text { ii) Partizipio } \\
\text { burutugabea }\end{array}$ & $\begin{array}{l}\text {-tzen } \\
\text { Pentsatzen }\end{array}$ & $\begin{array}{l}\text {-tan } \\
\text { Pentsetan } \\
\text { Ernegetan }\end{array}$ \\
\hline iii) Aditz-erroa & $\begin{array}{l}\text { Erabaki } \\
\text { Nahi }\end{array}$ & $\begin{array}{l}\text { Eretxi }{ }^{17} \\
\text { Gura }\end{array}$ \\
\hline iv) Modulatzailea & Omen & Ei \\
\hline $\begin{array}{l}\text { v) Aditz-laguntzai- } \\
\text { leak }\end{array}$ & $\begin{array}{l}\text { Zuen, zuten, ziren } \\
\text { Zekien. Zabiltza } \\
\text { Zatozte }\end{array}$ & $\begin{array}{l}\text { Zeuen, zaben, ziran } \\
\text { Ekian, Zabilz } \\
\text { Erduze }\end{array}$ \\
\hline vi) Konpletiboa & -la & -na \\
\hline vii) Errepikapena & $\begin{array}{l}\text { Esatea errazagoa } \\
\text { Basajaunek garia daukate, } \\
\text { eta ogia jaten dute, baina } \\
\text { guk ez }\end{array}$ & $\begin{array}{l}\text { Esan erraza da esatea } \\
\text { Basajaunek garia eduki } \\
\text { badeukie, eta ogia be jan } \\
\text { jaten dabe, baina geuk ez }\end{array}$ \\
\hline Lokailuak & Ere & Be \\
\hline
\end{tabular}

Hiztegiaren kasuan, ordea, Zuazok eta Goitik (2017) eta Mungiako ikastetxeak (2012) proposatutako Mungialdeko berbak erabili dira batueratik bizkaierara ipuina moldatzeko eta herriko hizkeran ohikoagoak diren berbak erabiltzeko. Moldaketa horiek 2. taulan jaso dira; alde batetik, Euskara Batuan Ohiko Hiztegia (EBOH) eta, bestetik, horien baliokide diren Bizkaiera eta Mungialdeko Hizkeraren Berezko Hiztegia (BMHBH) oinarri hartuta erabilitako berbak:

17 Taula honetan aditz-sistema osoa jaso da. Hiztegian egindako moldaketen taulan ere jaso da eretxi aditza. 
Ipuin-moldaketa herri-hizkerara egokitzeko eta modu esanguratsuan...

2. taula

Hiztegia moldatzeko taula

\begin{tabular}{l|l|l|l}
\hline \multicolumn{1}{c|}{ EBOH } & \multicolumn{2}{c}{ EBOH } & BMHBH \\
\hline Ahopean & Isilke-misilke & Hitz & Berba \\
Ale & Garau & Ideia & Burutazino \\
Aspertu & Abrozidu & Iritsi & Heldu \\
Berehala & Atoan & Itsusi & Motz \\
Bihurri & Barrabas & Jakintsu & Jakitun \\
Bikain & Itzelezko & Korrika & Karraderan/arrapaladan \\
Bilatu & Topau & Lapurtu & Ostu \\
Bildu & Batu & Laster & Segiduan \\
Bizkorra & Zuhurra & Mendian behera & Aurbehera \\
Desafioa bota & Gangarra altxau & Nahi & Gura \\
Erraldoi & Gizontzar & Ordea & Ostera \\
Eseri & Jarri & Oso & Sano \\
Esker & Graziak & Pixka bat & Apur bat \\
Ezkutatu & Ostondu & Proba & Saiakerea \\
Gai izan & Kapaz izan & Udazkena & Udagoiena \\
Garrasika & Poperreka & Urrun & Asau \\
Gizaki & Gizakume & Uste & Eretxi \\
Guztiak & Danak & Zabala & Nasaia \\
Haserre & Motxortuta/ernegauta & Erduze \\
Herri & Uri & & \\
\hline & & & \\
\hline
\end{tabular}

Moldaketak aurretiaz aipatutako sintaxi- eta hiztegi-egokitzapenak izateaz gain, Zuazok eta Goitik (2017) zehazten dituzten eta Mungialdeko hizkerak berezko dituen ezaugarri fonologikoak erabili dira irakurketan:

1. -a bokalean amaitzen diren berben kasuan, -e edo -ea erabili da. Adibidez, (1) garie, (2) ogie, (3) bustite edo (4) tranpea.

2. Berba euskaldunen hasieran (-)j- [y] ahoskatu da. Adibidez, (5) [y]an edo (6) [y]akina.

3. Herriko berbetan egiten denez eta Euskara Batuaren Ahoskera Zainduan (aurrerantzean EBAZ) onartzen denez, (-)s- eta (-)z- txistukariak [s] bezala egin dira eta (-)ts eta (-)tz-, [tz] bezala. 
4. Azentua talde fonologikoaren ${ }^{18}$ azken silaban jarri da orokorrean (Gaminde, 2002). Adibidez, (7) (...) hareek euki baeukean garié.

Azkenik, ipuinari tentsio eta adierazgarritasun handiagoa emateko, Amestoyren eta Martinezen (1992) Behin Bazen bildumako Martintxo eta Basajaunak ipuinean erabilitako teknika batzuk oinarri hartuta zenbait aldaketa egin dira balio pragmatikoz bertsio originala esanguratsuago egiteko. Horretarako, arriskua eta tentsioa areagotzen duten onomatopeiak (besteak beste zas), bolumena igotzea eta abiadura azkartzea eta entzuleak ekintzaren bat-batekotasuna senti dezan eta espazioan kokatu dadin laguntzen duten esaldiak erabili dira (ikus 8 . adibidea).

(8) Martin Txikik baekien basora heldukeran salbu egongo zala. Momentu batean entzun zeuzen basajaunak hurbilduten eta zas! Ikusi be, ikusi zeuen gauza bat beran ondotik pasetan. Aizkora bat zan.

\subsection{Ikasleen taldekatzea}

Lan hau osatzen duten jarduera guztiak 9 haurrekin egin dira. Horiek 3 umeko 3 taldetan bildu dira emaitzak konparatzeko. Haurren aukeraketa egiteko, kontuan izan den irizpidea euren ama-hizkuntza izan da. Lehenengo taldea ama-hizkuntza euskara batua duten haurrez osatuta dago; bigarrena, ama-hizkuntza euskara duten euskalkidunez eta hirugarrena, aldiz, ama-hizkuntza gaztelania duten haurrez. ${ }^{19}$

Haurrek bakarka egin dituzte jarduerak euren ama-hizkuntza zein den kontuan hartuta. Salbuespena 3.3.5. azpiatalean azalduko den jarduerarako egindako taldekatzea da. Jarduera horretan hiru talde ezberdin sortu dira, A taldea, B taldea eta $\mathrm{C}$ taldea. Talde horiek ama-hizkuntza euskara batua, euskalkia eta gaztelania duten haurrez osatu dira modu mistoan, elkarrizketa elkarreragileen bidez ikasi dutena aztertzeko. Beraz, helburua da ikasleek euren artean, eta irakasleak beharrezko aldamioa jarriz, elkarrizketa bidez ikasi dutena aztertzea eta beste haurrengan duten eragina zehaztea. Esaterako, B taldea ama-hizkuntza euskara batua duen haur batez eta ama-hizkuntzatzat euskalkia duten bi haurrez osatuta dago. Hala ere, lagina ikasgelako egoerara

18 Talde edo esaldi fonologikotzat hartzen da egitura sintaktiko batean dagoen talde klitiko bat edo gehiagoren multzoa (Elordieta, 2008), eta Aurrekoetxea et al.-en (2015) arabera (2015), talde klitikoa da autonomia prosodikorik ez duten eta silaba bat edo bi dituzten hitzak. Kasu honetan, ondoren duen hitzarekin batera ahoskatzen da. Klitikotzat hartzen dira $e z, b a, d a$ adizkia eta aditz sintetiko guztiak.

${ }^{19}$ Lan honen bidez ateratako emaitzen interpretazioa nabarmenagoa litzateke gelako haur guztiak kontuan hartuz edota gela ezberdinetan esperimentua eginez. Hala ere, egindako azterketaren sakontasunak metodoa eta aurretiaz zehaztutako hipotesiak probatzeko aukera nahikoa eman digula uste dugu eta horri eman diogu garrantzia ondo dokumentatuz. 
Ipuin-moldaketa herri-hizkerara egokitzeko eta modu esanguratsuan...

moldatu behar izan da, haur euskaldunen kopuruak mugatu baitu taldeak egiteko aukera hori. 3. taulan jasotzen dira taldeak eta horien osaketa:

3. taula

Ahozko adierazpenerako ataza egiteko taldeak

\begin{tabular}{cccc}
\hline Taldea & Batua & Euskalkia & Gaztelania \\
\hline A & 1 & 1 & 1 \\
B & 1 & 2 & \\
C & 1 & & 2 \\
\hline
\end{tabular}

\subsection{Esku-hartzea eta datu-bilketa}

Ipuina moldatuta, proposamen didaktikoa diseinatzeko zenbait fase eta fase bakoitzean hainbat jarduera sortu dira, aurretiaz aipatutako metodologia konstruktibistan oinarrituta eta betiere haurren ama-hizkuntzaren aniztasuna kontuan hartuz. Esku-hartzea osatzen duten aurretiazko, bitarteko eta ondorengo jarduerak 3. irudian jaso dira:

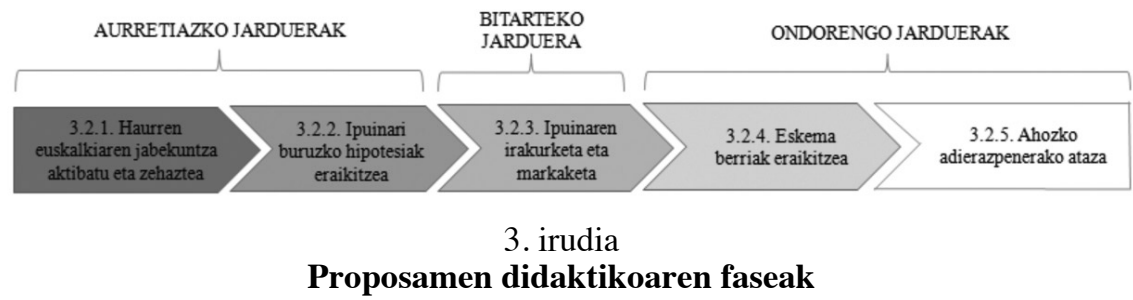

Jarduera guztien ostean, haurrek erakutsitako hizkuntza- eta komunikazio-gaitasunari buruzko datuak euskarri ezberdinetan (grabaketak, behaketa-orriak eta fitxak) jaso dira.

Horietan guztietan jasotako datuak izan dira lan honetako ikerketaren oinarri eta, beraz, zehaztutako helburu eta hipotesien betetzea baieztatu edo ezeztatzeko aztertu dira, emaitzen atalean.

\subsubsection{Haurren euskalkiaren jabekuntza aktibatu eta zehaztea}

Ipuina kontatu aurretik haurrekin jarduera bat egin da, euren hizkuntzaaurrezagutzak zeintzuk diren zehazteko asmoz. 
Haur bakoitzari banaka irudi batzuk aurkeztu zaizkio. Irudi horiek sortu dira Martin Txiki eta Basajaunak ipuinean agertzen diren ekintzak eta kontzeptuak erakusteko. Irudiok bikoteka antolatu dira, kontrako kontzeptuak edo jarduerak ${ }^{20}$ erakutsiz. Hau da, bikoteetako batean adibidez (ikusi 4. irudia), herria eta mendia erakutsi dira, haurrek ezberdintasuna modu argian ikus dezaten.

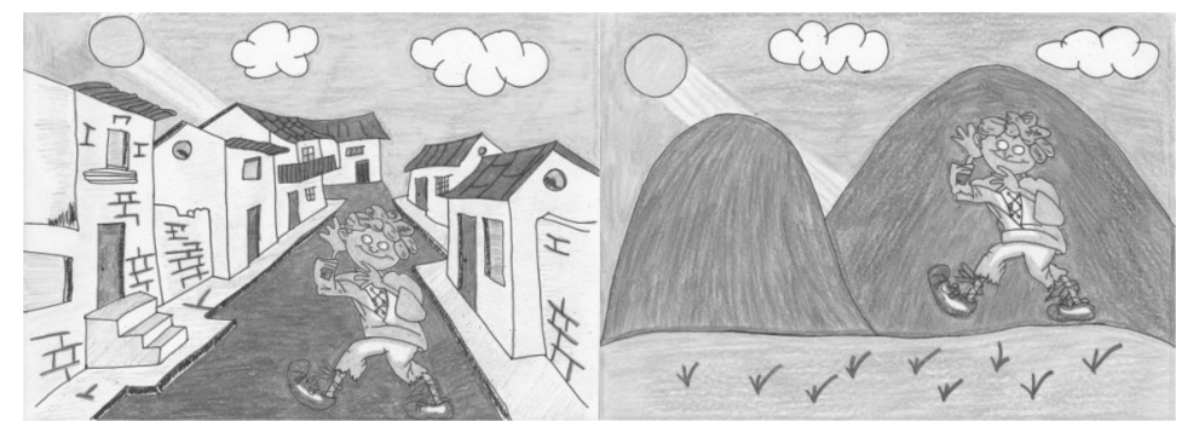

4. irudia

Kontrako kontzeptuak erakusteko eredua

Bikote bakoitzean ageri den kontzeptu edo jardueretako bat (4. taulan jasotako bikote bakoitzeko lehenengoa) geroago irakurri zaien ipuinean aipatu da. Guztira hamabi bikote erabili dira hurrengo izen, izenondo, aditz eta aditzondoetan antolatuta:

4. taula

Kontrako kontzeptuen eta jardueren taula

(ezkerrean bizkaieraz, eskuman batueraz)

\begin{tabular}{c|l|l|l}
\hline \multicolumn{1}{c|}{ IZENAK } & \multicolumn{1}{c|}{ IZENONDOA } & \multicolumn{1}{c}{ ADITZAK } & \multicolumn{1}{c}{ ADITZONDOAK } \\
\hline Uria - Mendia & Motza - Polita & Gura - Gura izan ez & Karraderan edo arrapaladan - Geldi \\
\hline Gari garaua - Garia & & Jarri - Altxatu & Apur bat - Asko \\
\hline Udagoiena - Negua & & Berba egin - Isildu & Asau - Hurbil \\
\hline & & Ostendu - Agertu & Aurbehera - Aldats gora \\
\hline
\end{tabular}

Haurrei irudi-bikote bakoitzean zer ikusten duten galdetu zaie hurrengo itaunak erabiliz:

${ }^{20}$ Haur Hezkuntzan teknika hau erabili ohi da lexikoa ikasteko. 
Ipuin-moldaketa herri-hizkerara egokitzeko eta modu esanguratsuan...

a) Izenen kasuan: Zer ikusten duzu irudi honetan? Zelan esaten dute etxean? Eta zure aititek eta amamak?

b) Izenondoaren kasuan: Nolakoak dira basajauna eta mutila? Zelan esaten dute etxean? Eta zure aititek eta amamak?

c) Aditzen kasuan: Zer ari da egiten Martin Txiki? Zer gertatzen zaio Martin Txikiri? Zelan esaten dute etxean? Eta zure aititek eta amamak?

d) Aditzondoen kasuan: Nola dabil Martin Txiki? Zenbat gari garau hartu du? Non daude Martin Txiki eta Basajaunak? Zelan esaten dute etxean? Eta zure aititek eta amamak?

Jarduera egin ostean (audioa grabatu egin da) haurrek emandako erantzunak jaso dira, zehaztuz haur bakoitzak erabilitako hitza bizkaierari, euskara batuari ala gaztelaniari dagokion eta haur bakoitzaren ama-hizkuntza zein den. Horrek balio izan digu haurrek dituzten hizkuntza-aurrezagutzak zeintzuk diren ezagutzeko eta kuantifikatzeko eta $\mathrm{H}_{2.1}, \mathrm{H}_{2.3}$, eta $\mathrm{H}_{2.5}$ hipotesiak baieztatzeko ala ezeztatzeko.

\subsubsection{Ipuinaren sekuentziari buruzko hipotesiak eraikitzea}

Jarduera honetan lehenengoz erakutsi zaizkie haurrei Martin Txiki eta Basajaunak ipuineko irudiak. Ariketaren helburua bikoitza izan da. Alde batetik, haurrek ipuinean agertutako argumentuari buruzko hipotesiak egin dituzte. Horrela, hizkuntza- eta komunikazio-gaitasuna garatzeko aukera eskaini zaie. Beste alde batetik, aurre-ebaluazioa egiteko jarduera ere bada. Hau da, haurrek hipotesiak egitean, erabilitako hizkuntza zein den ikusi da jarduera honetan, euren ama-hizkuntza eta komunikazio- eta hizkuntzagaitasunak zeintzuk dituzten azaletik zehaztuz. Beraz, lan honetan zehaztutako $\mathrm{H}_{1}$ eta $\mathrm{H}_{2.1}, \mathrm{H}_{2.3}$, eta $\mathrm{H}_{2.5}$ hipotesiak betetzen diren aztertzeko erabili dira jarduera honetako emaitzak, 3.2.5 jardueran erakutsitako gaitasunarekin alderatzeko balio izango baitu.

Berriro ere ikasleak banan-banan jarrita, irudi batzuk aurkeztu zaizkie haurrei. Irudi horiek Martin Txiki eta Basajaunak ipuinetik hartu dira, inolako moldaketarik egin gabe eta narrazioaren une esanguratsuak erakusteko asmoarekin. Aipatutako irudiok ondokoak dira (ikusi 5., 6., 7. eta 8. irudiak): 
a) Martin Txiki abarkak janzten ikusten den irudia.

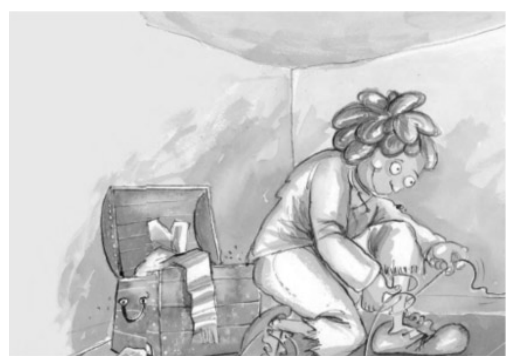

5. irudia

Hipotesiak eraikitzeko irudia

c) Basajaunak Martin Txikiren atzetik doaz harrapatu nahian.

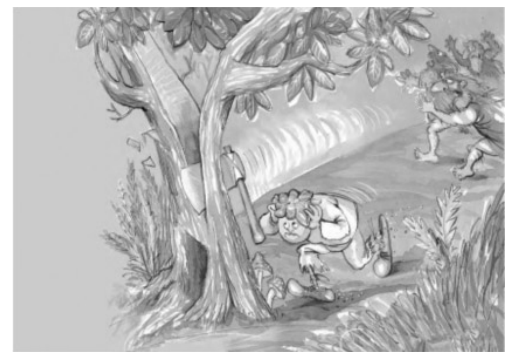

7. irudia

Hipotesiak eraikitzeko irudia b) Martin Txikik gari-metaren gainera salto egiten du.

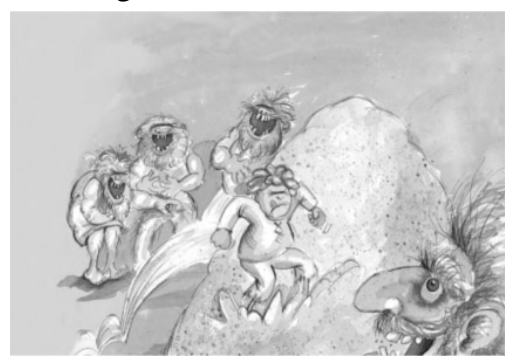

6. irudia

Hipotesiak eraikitzeko irudia

d) Martin herrira heldu eta herritarrei gari garauak erakusten dizkie.

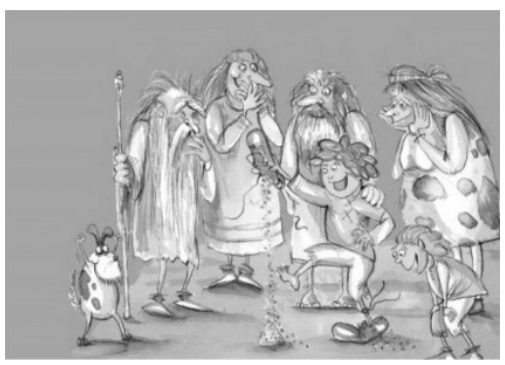

8. irudia

Hipotesiak eraikitzeko irudia

Jarduera honetan, alde batetik, aztertu da haurrek hipotesiak egiteko sekuentziak ordenatu eta diskurtso koherentea sortzeko gai izan diren. Beste alde batetik, haurrekin izandako elkarrizketak aztertzeko haurren hizkuntza- eta komunikazio-gaitasunari buruzko ondoko galderak aztertu ditugu, haurren aurrezagutzak zeintzuk diren zehazten laguntzeko:

a) Haurrak gai dira diskurtso ulergarria eraikitzeko laguntza semantikorik gabe eta elkarrizketan gutxieneko erantzuna emanda. Horrek $\mathrm{H}_{1}$ hipotesiaren betetzea aztertzen lagunduko digu.

b) Haurrek euskara batua erabiltzen dute bere diskurtsoan. Horrek $\mathrm{H}_{2}$ hipotesiaren betetzea aztertzen lagunduko digu.

c) Haurrek euskalkia erabiltzen dute bere diskurtsoan. Horrek $\mathrm{H}_{2}$ hipotesiaren betetzea aztertzen lagunduko digu.

d) Haurrek estrategia moduan maileguak erabiltzen dituzte diskurtsoa eraikitzeko. Horrek $\mathrm{H}_{2}$ hipotesiaren betetzea aztertzen lagunduko digu. 
Ipuin-moldaketa herri-hizkerara egokitzeko eta modu esanguratsuan...

\subsubsection{Bitarteko jarduera: Ipuinaren markaketa eta irakurketa}

Ahozkotasuna garatzeko input esanguratsuak haurren ahozko komunikazio-gaitasunean duen eragina erakusteko xedearekin, Haur Hezkuntzako lau urteko gela bateko haurrei ipuin bat irakurri zaie. Irakurketa bost saiotan egin da, guztiak 15 minutukoak. Lehenengo bi irakurraldiak ipuin originala (euskara batuan) erabiliz egin dira, baina hurrengo hirurak, ordea, Mungialdeko euskalkian EBAZ jarraituz. Bost saioetan Martin Txiki eta Basajaunak ipuinak dituen irudi originalak erabili dira inputaren ulergarritasunari laguntzeko. Helburu berarekin, irakurleak erabiliko dituen keinuei ere arreta berezia eskaini zaie; hau da, irakurleak irakurketa keinuz lagundu du, haurrek narrazioa hobeto uler dezaten. Azkenik aipatu nahi da, saio bi grabatu direla, bata euskara batuaren erabileraren eredu izateko (kasu honetan ipuinaren testu originala erabili da $)^{21}$ eta bestea, euskalkiaren erabileraren eredu izateko ${ }^{22}$. Beraz, haurrek egiten duten euskalkiaren erabileran duen eragina neurtu nahi da aipatutako input esanguratsuak aztertuz.

Irakurketa modu esanguratsuan egiteko, erabili dira Garcia-Arriolak eta Iruskietak (2016) proposatutako hizkuntzaren balio pragmatikoa lantzeko estrategiak (bolumena, ahoskera, intonazioa, etenak, abiadura, lapsusak) eta Aizpuruak, Beaskoetxeak, Karrillok eta Iruskietak (2018) proposatutako markaketa-sistema, euskara batuan eta bizkaierazko bertsioan. ${ }^{23}$ (9) adibidean jaso da bizkaieraz dagoen testuaren lagina. Zati horretan ikus daiteke irakurketa erraztuko duen markaketa grafikoa; geziekin intonazioa gora edo behera doan markatzen da, letra larriek bolumen ozena adierazten dute, barra okerrek eten laburrak (barra bakarra) eta luzeak (barra bikoitza) adierazten dituzte, gidoiek abiadura murrizteko balio dute eta azentua ere markatzen da, nolabait sintagma esanguratsuetan.

(9) Munduen / BASÁ $<Y>A U N A ́ K \quad B A I<\tilde{N}>O$ EZaben ogirík ${ }^{\prime}$ $<y>a t e n \searrow$.// HAREEXEK BAI GIZONTZARRAK! // Basá<y>aunák/ ERRALDOI [gora begiratu] $<Y>A K I T U N$ BATZUK $\nearrow$ ziran $\searrow$.// Arálarrekó mendietán bizi ziran \,// eta hareexek bai, \/ [buruarekin baietz] hareek euki baeukean` garié $\searrow, /$ bai $<\tilde{\mathbf{n}}>a \searrow / G I-Z A-K U-M E I \nearrow$ [buruarekin ezetz] EZ ZO-TSI-EN E-MON GU-RA izaten ` .//

Bideo grabaziotik ateratako zatian PRAAT tresnarekin (Boersma, 2002) adibideko lehen esaldia aztertu dugu ${ }^{24}$ 9. irudian eta bertan ikus dezakegu «munduen» hitzaren ondoren eten laburra egin duela eta markatu-

21 Bideoaren esteka: https://addi.ehu.es/handle/10810/31766.

22 Bideoaren esteka: https://addi.ehu.es/handle/10810/31766.

${ }^{23}$ Irakurketa ozena egiteko beste markaketa-sistema bat Segurak (2016) proposatu zuen. Lan horretan helduen euskalduntzean eta alfabetatzean behe (A1 eta A2) eta goi mailetan (C1 eta $\mathrm{C} 2$ ) lantzeko moduko zenbait adibide proposatzen ditu irakurketa ozena praktikatzeko.

${ }^{24}$ Analizaturiko soinu fitxategia lortzeko, bideo fitxategia MP4 formatutik MP3 formatura pasatu dugu VLC programarekin eta ondoren Audacity programarekin estereotik mo- 
tako hitzetan intonazioa igo duela, galdegaia den hitzean igo du gehien intonazioa.

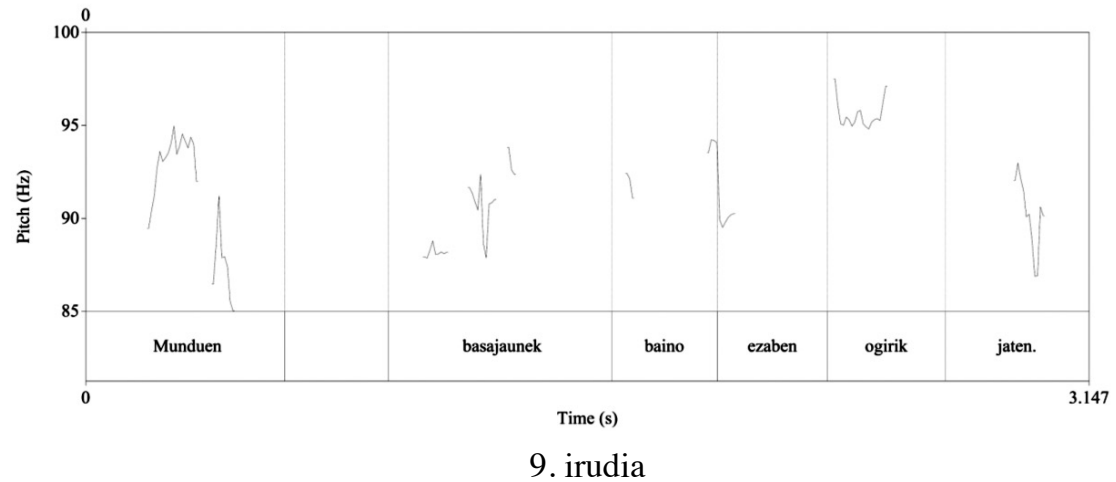

PRAAT tresnarekin analizaturiko zatia

Marka horiez gain, adibide horretan parentesi karratuen artean adierazi da irakurtzen den bitartean egin beharreko keinuak zeintzuk diren. 10. irudian ikus daitezke keinuok, bideo grabaziotik erauzita.

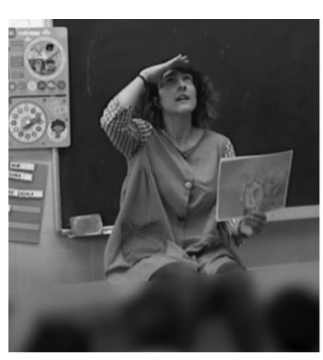

Gora begiratu (ezkerrean), buruarekin baietz (erdian) eta buruarekin ezetz (eskuinean)

Balio pragmatikoari eman zaion garrantziaz gain, keinuen erabilerari garrantzia handia eman zaio, horrek irakurketari esangura ematen baitio eta efektu hori sortzea komeni baita haurren ahozko komunikazio-gaitasunen garapenean laguntzeko, areago Haur Hezkuntzan haurrek duten hizkuntzaren jabekuntza maila txikiagoa dela kontuan hartuta. Markatu diren keinuok honela antolatu dira:

nora pasatu dugu, PRAAT programarekin modu egokian aztertzeko. Ez diogu atzeko zaratarik kendu audio fitxategiari. 
a) Entzuleekiko kontaktua indartzeko keinuak.

Ipuinaren irakurketa jesarrita eta haurrak aurrean jesarrita daudela egin dugu. Horretarako, argitaratutako ipuinak dituen irudiak erabili dira, haurren arretari eusteko. Helburu berberarekin, haurrak geldi egoteko eta arreta mantentzeko, uneoro begirada beraiengan atxiki da, modu indibidualean askotan.

b) Pertsonaiek egindako ekintzak egitea.

Zenbait kasutan, pertsonaiek egindako ekintzak gorputz osoarekin irudikatu dira, berriro ere haurren gaitasun linguistikoa osatzeko helburuz. Adibidez, Basajaunek garia botatzen dutela irudikatu dugu, lan egiteko kanta abesten duten bitartean. Gainera, Martin Txikik korrika egiten duenean ere, beso eta gorputzaren mugimenduarekin lagundu dugu ekintza hori eta, azkenik, Basajaunek aizkora botatzen diotenean ere makurtu egin gara.

c) Pertsonaien ekintzak irudikatzeko keinuak eskuekin adieraztea.

Beste kasu batzuetan pertsonaien ekintzak eskua erabiliz bakarrik egin ditugu. Adibidez, Martin Txikik gari piloaren gainetik salto egiten duenean, saltoa eskuarekin egin dugu eta, erortzen denean ere, gu erori beharrean, eskua jausten uzten dugu, denborak eta espazioak narrazioarekin bat egiteko.

d) Istorioa eta pertsonaiak espazioan kokatzeko keinuak.

Besteak beste, istorioan goia eta behea keinuekin adierazi dira, kontuan hartuz basajaunak Martin Txiki baino altuagoak direla eta, hortaz, pertsonaiek hitz egiten dutenean basajaunek uneoro behera begiratu dute eta Martin Txikik gora.

Istorioari dagokionez, narratzaileak gari piloa seinalatu du eta horren gainetik salto egiteko jarraitutako ibilbidea eta mugimendu sekuentzia irudikatu ditu.

e) Objektuak aurkezteko edo irudikatzeko keinuak.

Kontakizunean zenbait keinu erabili ditugu garrantzia duten objektuak aurkezteko eta, ondorioz, haurrei horiek irudikatzen laguntzeko. Adibidez, ogia eskuarekin hartzeko imintzioa egin dugu, gari piloak nolako forma duen irudikatu dugu, abarkak lotu ditugu eta abarken barruan dagoen garia lurrera bota dugu.

f) Kontakizunari gorputzarekin indarra eta erritmoa emateko keinuak. Keinu hauekin lortu nahi da entzuleek kontakizunean arreta eta interesari eutsi diezaioten. Adibidez, Martin Txikik gari piloaren gainetik salto egiten duenean eta gari piloaren gainera erori baino lehen, eskua geldi mantentzen da airean kontakizunari tentsioa emateko. Gainera, Martintxo herrira bueltan doanean, burua beherantz duela dabil, horrek kontakizunaren erritmoa moteltzen duelarik. 
g) Sentimenduak adierazteko keinuak.

Pertsonaien sentimenduak erakusteko keinuak ere erabiltzen dira kontakizunean. Ogia lortzeko desioa erakusteko, gozo dagoela erakusten duen keinua egiten da mihiarekin eta pozik dagoela adierazten da irribarrearekin. Martin Txiki haserre dagoenean, ordea, burua behera darama eta bihurri aurpegia ere jartzen du.

Lanean sortutako materiala hezkuntza-testuinguruetan erabiltzeko asmoarekin, lana egin ondoren, bizkaieraz kontatutako ipuinaren keinuak MOODLEn markatu ditugu eduki interaktiboa eginez. Alde batetik, keinuak markatu ditugu eta, beste aldetik, keinuen gainean klik eginda keinuaren funtzioa agertzen da. Esaterako, 11. irudian «gora begiratu» botoiaren gainean klik eginda «istorioa eta pertsonaiak espazioan kokatzeko keinuak» funtzioaren azalpena agertzen da. Horrela, material hori beste ikasleentzat ere baliagarria izango da.

Batueraz kontatutako ipuinean ere keinuak aztertu dira VideoAnt sistemarekin. Egia esan, sistema horrekin gauza bera egin da. Sisteman erabiltzailea lortzea eta etiketatzea errazagoa da, baina tamalez ez du ikusentzunezko materialak bete behar duen espazio hurbiltasunaren baldintza betetzen (García, Rigo eta Jiménez, 2017). Ikaslea bideoa ikusten ari denean, keinuen etiketak irakurtzeko beste alde batera begiratu behar du, eta horrek irudian gertatzen dena ezin ikustea eta informazioa galtzea ekar dezake.

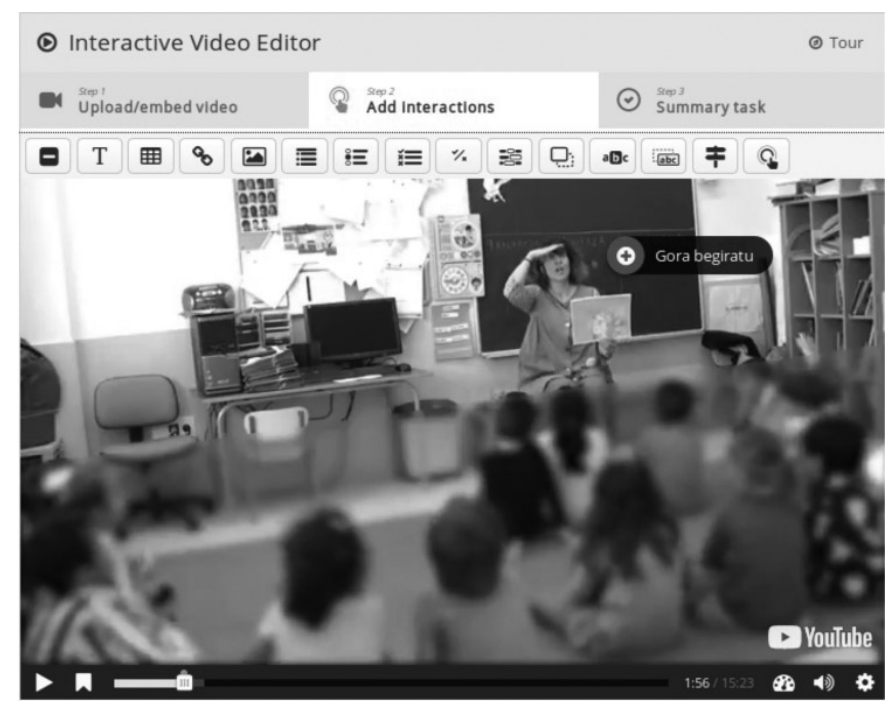

11. irudia

Gora begiratu keinua etiketatzen MOODLEn 


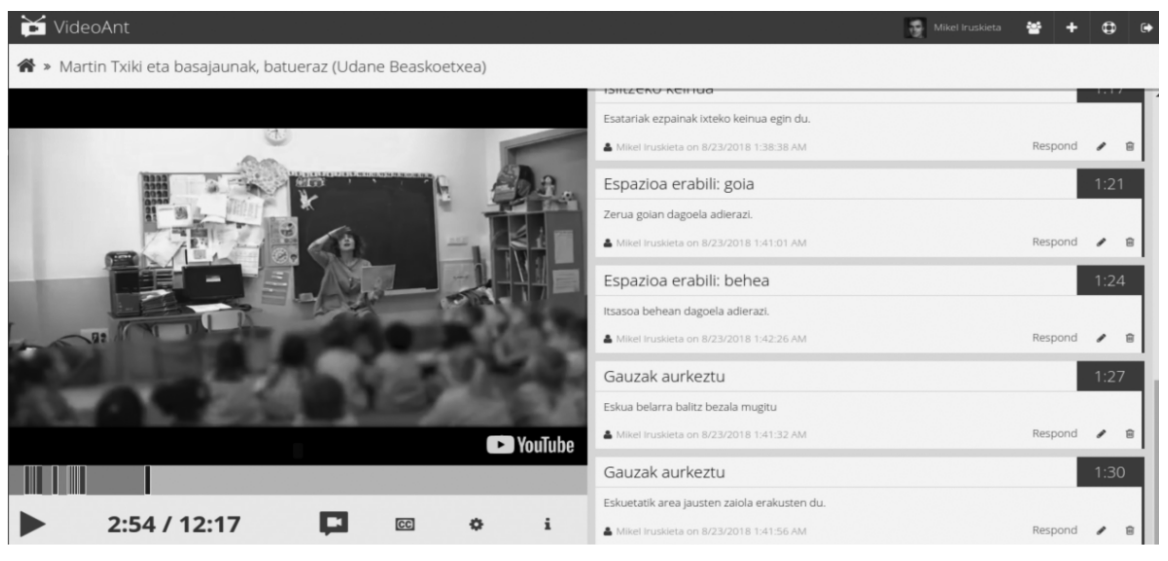

12. irudia

VideoAnt sistemarekin egindako etiketatzea

\subsubsection{Eskema berriak eraikitzea}

Fase honetan, ipuina irakurri aurretik aurrezagutzak zehazteko jarduera bera (3.3.1 fasean azaldutakoa) errepikatu da, baldintza berberetan. Hasteko, galdeketa bederatzi haurrei egin zaie, euren ama-hizkuntza euskara batua, euskalkia edo erdara den kontuan hartuta. Bigarrenez, erabili diren irudiak berdinak izan dira eta horiek erabili dira ipuinean aipatzen diren hitzak esatera bideratu eta zein hizkuntza edo euskalki erabiltzen duten ikusteko. Azkenik, egin zaizkien galderak ere berdinak izan dira. Galdera horiek erabili dira, haurrak hitz zehatzak esatera bideratzeko.

Jarduera honen helburua, ipuina kontatzeak haurren outputean eraginik duen ikustea da. Hau da, hizkuntzari buruz aurretiaz dituzten ezagutzen gainean ezagutza berriak eraiki diren ikusi nahi da.

Oraingoan ere, haurrek irudietan agertutakoa izendatzeko euskalkia, batua edo maileguak erabili dituzten aztertu da. Edozein kasutan, bizkaierazko outputa egiteko gai diren ikusteko, ipuina bizkaieraz kontatu denean zelan esan den galdetu zaie (Zelan landu dugu bizkaieraz hori?). Ondoren, 3.3.1 azpiatalean erabilitako hiztegia alderatu eta input esanguratsuak haurren hizkuntza-gaitasunean izan dituen eraginak zehaztu dira. Horrela lortu da, 3.3.1 azpiatalean egindakoarekin alderatuta, $\mathrm{H}_{2.2}, \mathrm{H}_{2.4}$, eta $\mathrm{H}_{2.6}$ hipotesiak baieztatzea edo ezeztatzea.

\subsubsection{Ahozko adierazpenerako ataza}

Txosten honetako esparru teorikoan azaldu den legez, hizkuntza gehienbat elkarrizketa elkarreragileen bidez ikasten da. Hori da azken jarduera honen helburua: haurrei euren artean eta irakasleak beharrezko al- 
damioa jarriz, elkarrizketa bidez hizkuntzari buruz eraikitako ezagutzak egonkortzea eta haurren eta irakaslearen hizkuntza-ezagutzek beste haurrengan duten eragina zehaztea.

3.2 azpiatalean aipatutako talde misto bakoitzeko (A taldea, B taldea eta $\mathrm{C}$ taldea) haurren artean elkarrizketa bultzatu duen honako galdera eragile hau plazaratu zaie: Zer gertatuko litzateke Martintxok gari-metaren gainetik salto egitea lortuko balu ${ }^{25}$ Erantzuna eman nahian, ipuinaren amaiera aldatzeko ataza egin dute eta, hortaz, eraikitako hizkuntzari buruzko ezagutzak egonkortu eta komunikazio-praktika ezberdin batean erabiltzeko aukera eman zaie, arreta berezia eskainiz bizkaierazko hizkuntzaeta komunikazio-gaitasunak garatu diren.

Jarduera honen ebaluazioa egiteko haurren elkarrizketen audioak grabatu dira eta 3.3.2 azpiatalean aipatutako ezaugarriak aztertu dira, haurrek erabilitako hizkuntzan euskalkiak eraginik izan duen ondorioztatzeko eta $\mathrm{H}_{1}$ eta $\mathrm{H}_{2.2}, \mathrm{H}_{2.4}$ eta $\mathrm{H}_{2.6}$ hipotesiak bete diren zehazteko.

\section{EMAITZAK}

Lanaren atal honetan aurretiaz azaldutako esku-hartzeari dagozkion jardueren emaitzak bildu dira. Horretarako, metodologian jasotako egiturari jarraitu zaio, haurren aurretiazko eta ipuina kontatu osteko hizkuntzaeta komunikazio-gaitasunen inguruko emaitzak zehazteko eta horiek alderatzeko. Horrez gain, artikulu honen sarreran hipotesi batzuk ageri dira ama-hizkuntza euskara batua, euskalkia edo gaztelania duten haurrentzako. Hori dela eta, emaitzak haurren ama-hizkuntzaren arabera antolatuko dira, hipotesiak bete diren eta, hala bada, zein gradutan bete diren zehaztuz. ${ }^{26}$

\subsection{Haurren euskalkiaren jabekuntza aktibatu eta zehaztea}

Aurrezagutzak aktibatu eta zehazteko jardueran, haurrek ipuina irakurri aurretik erabilitako hiztegia ebaluatu da, horretarako kontrakotasuna adierazten duten irudiak (3.3.1 puntuan jasotakoak) eta haurren hiztegia konparatzeko taula erabilita. Taula horretan jaso diren datuetatik emaitza orokorrak atera dira haurren ama-hizkuntzaren arabera, $\mathrm{H}_{2.1}, \mathrm{H}_{2.3}$ eta $\mathrm{H}_{2.5}$ hipotesien betetzea ondorioztatzeko. Emaitza orokor horiek 5. taulan laburbildu dira. Bertan jasotzen dira haurren ama-hizkuntza zein den eta eus-

${ }^{25}$ Haurrei laguntzeko Martin Txikik gari piloaren erdira salto egiten ikusten den irudia aldatu da, beste aldera salto egiten duela erakusteko.

26 Aipatu behar da esku-hartzea Practicum III irakasgaia egiteko ikasgelan egin dela eta praktikek iraun bitartean haurrekin euskalkia erabili dela. Irakasle-tutoreak ere hala egiten du ahozko komunikazioan eta horrek eragina izan dezake emaitzetan. 
Ipuin-moldaketa herri-hizkerara egokitzeko eta modu esanguratsuan...

kara batuan eta euskalkian erabilitako hitzen, maileguen eta ez dakizkiten hitzen kopuruak eta horiei dagozkien portzentajeak:

5. taula

Haurren aurrezagutzak hizkuntzari buruz

\begin{tabular}{l|l|c|c|c|c|c|c|c|c}
\hline \multirow{2}{*}{$\begin{array}{c}\text { Ama- } \\
\text { hizkuntza }\end{array}$} & \multirow{2}{*}{ Ikaslea } & \multicolumn{2}{c|}{$\begin{array}{c}\text { Euskara batuan } \\
\text { erabilitako hitzak }\end{array}$} & \multicolumn{2}{c|}{$\begin{array}{c}\text { Euskalkian } \\
\text { erabilitako hitzak }\end{array}$} & \multicolumn{2}{c|}{ Maileguak } & \multicolumn{2}{c}{$\begin{array}{c}\text { Ez dakizkien } \\
\text { hitzak }\end{array}$} \\
\cline { 3 - 11 } & & Kopurua & $\bar{X}$ & Kopurua & $\bar{X}$ & Kopurua & $\bar{X}$ & Kopurua & $\bar{X}$ \\
\hline \multirow{3}{*}{ Euskalkia } & Ikasle 127 & 5 & & 4 & & 2 & & 2 & \\
& Ikasle 2 & 5 & $\mathbf{3 6 , 9 7}$ & 6 & $\mathbf{3 9 , 7 4}$ & 0 & $\mathbf{1 5 , 3 8}$ & 1 & 18,16 \\
& Ikasle 3 & 4 & & 5 & & 0 & & 4 & \\
\hline \multirow{3}{*}{ Batua } & Ikasle 4 & 8 & & 4 & & 0 & & 1 & \\
& Ikasle 5 & 3 & 31,62 & 4 & $\mathbf{3 2 , 4 8}$ & 0 & 0 & 5 & 35,90 \\
& Ikasle 6 & 1 & & 4 & & 0 & & 7 & \\
\hline \multirow{3}{*}{ Gaztelania } & Ikasle 7 & 2 & & 2 & & 1 & & 7 & \\
& Ikasle 8 & 4 & 19,44 & 1 & 13,89 & 3 & $\mathbf{1 3 , 8 9}$ & 4 & $\mathbf{5 2 , 7 8}$ \\
& Ikasle 9 & 1 & & 2 & & 1 & & 8 & \\
\hline
\end{tabular}

Taula horretan ikus daiteke, ama-hizkuntza euskalkia duten haurren kasuan, lehenengo ikaslearen kasua kenduta, haur hauek erabiltzen duten hiztegi gehiena euskalkiak berezkoa duena dela (batez beste \% 39,74), nahiz eta batueradunekin alde handirik izan ez (batez beste \% 36,97). Beraz, $\mathrm{H}_{2.1}$ hipotesia bete egin da. Horrez gain, aipagarria da ez dutela orokorrean mailegurik erabiltzen, berriro ere lehenengo ikaslearen kasua salbuespena delarik $(\% 15,38)$, baina euskalkian arrunta izan ohi da hori kasu batzuetan.

Ama-hizkuntza batua duten haurren kasuan, euskalkian erabilitako hitzen kopurua gailentzen da alde oso txikiz (batez beste \% 32,48 vs \% 31,62), ez dakizkiten hitzen kopurua oso altua da, baina. Epe ertainera begirako behaketan oinarrituta, haur horien segurtasun faltak eragindakoak izan daitezke emaitzok. Dena dela, hiru haurrek erabiltzen dute bizkaierak berezko duen hiztegia, hein txikiagoan bada ere. Hori dela eta, $\mathrm{H}_{2.3}$ hipotesia ez da bete.

Ama-hizkuntza gaztelania duten haurren kasuan, adierazgarriena da ez dakizkiten hitzen (batez beste \% 52,78) eta erabilitako maileguen (batez beste \% 13,89) kopurua. Horrez gain, gutxi bada ere, bizkaierak berezko

27 Jesarri eta gitxi hitzak bizkaierazkoak direla ulertu da eta taulan jasotako hitz multzo bakoitzean hitz bat barik bi esan direnean biak zenbatu dira. Taula guztietan egin da hori.

28 Arin hitza euskalkiari gehiago hurbiltzen zaiola ulertu da kasu guztietan. 
duen hiztegia ere erabili dute. Beraz, $\mathrm{H}_{2.5}$ hipotesia bete egin da hitz ezezagun eta maileguen erabilerari dagokionean, baina ipuina irakurri aurretik zenbait hitz erabili dituzte bizkaieraz.

\subsection{Eskema berriak eraikitzea}

Ipuina kontatu ondoren, irakurketa esanguratsuak izan duen eragina neurtzeko jarduerak egin dira. Hasteko, berriro ere 3.3.1 puntuan jasotako kontrakotasuna adierazten duten irudiak erabili dira eta 6. taulako emaitzak jaso dira. Bertan jaso dira haur bakoitzaren ama-hizkuntza zein den eta ipuina irakurri ostean haurrek euskara batuan eta euskalkian erabilitako hitzen, maileguen eta ez dakizkiten hitzen kopuruak eta portzentajeak. Kopuru horiek ipuina irakurri aurretik lortutako emaitzekin alderatu dira 6. taulan, haurrek izan duten garapena zein izan den modu kuantitatiboan ondorioztatu eta $\mathrm{H}_{2.2}, \mathrm{H}_{2.4}$ eta $\mathrm{H}_{2.6}$ hipotesiak bete diren ikusteko.

6. taula

Haurrek hizkuntzari buruz eraikitako ezagutzak

\begin{tabular}{|c|c|c|c|c|c|c|c|c|c|}
\hline \multirow{2}{*}{$\begin{array}{c}\text { Ama- } \\
\text { hizkuntza }\end{array}$} & \multirow{2}{*}{ Ikaslea } & \multicolumn{2}{|c|}{$\begin{array}{c}\text { Euskara batuan } \\
\text { erabilitako hitzak }\end{array}$} & \multicolumn{2}{|c|}{$\begin{array}{c}\text { Euskalkian } \\
\text { erabilitako hitzak }\end{array}$} & \multicolumn{2}{|c|}{ Maileguak } & \multicolumn{2}{|c|}{$\begin{array}{l}\text { Ez dakizkien } \\
\text { hitzak }\end{array}$} \\
\hline & & Kopurua & $\overline{\mathrm{X}}$ & Kopurua & $\overline{\mathrm{X}}$ & Kopurua & $\overline{\mathrm{X}}$ & Kopurua & $\overline{\mathrm{X}}$ \\
\hline Euskalkia & $\begin{array}{l}\text { Ikasle } \mathbf{1}^{29} \\
\text { Ikasle } \mathbf{2} \\
\text { Ikasle } \mathbf{3}\end{array}$ & $\begin{array}{l}8 \\
6 \\
5\end{array}$ & 41,07 & $\begin{array}{l}6 \\
9 \\
7 \\
\end{array}$ & 47,92 & $\begin{array}{l}0 \\
0 \\
0\end{array}$ & 0 & $\begin{array}{l}2 \\
1 \\
2\end{array}$ & 11,01 \\
\hline Batua & $\begin{array}{l}\text { Ikasle } 4^{30} \\
\text { Ikasle } 5 \\
\text { Ikasle } 6 \\
\end{array}$ & $\begin{array}{l}8 \\
6 \\
3 \\
\end{array}$ & 35 & $\begin{array}{c}12 \\
8 \\
4\end{array}$ & 48,89 & $\begin{array}{l}0 \\
0 \\
0\end{array}$ & 0 & $\begin{array}{l}0 \\
1 \\
5\end{array}$ & 16,11 \\
\hline Gaztelania & $\begin{array}{l}\text { Ikasle } 7 \\
\text { Ikasle } 8 \\
\text { Ikasle } 9\end{array}$ & $\begin{array}{l}5 \\
5 \\
2\end{array}$ & 30,56 & $\begin{array}{l}3 \\
3 \\
3\end{array}$ & 23,33 & $\begin{array}{l}1 \\
3 \\
1\end{array}$ & 12,22 & $\begin{array}{l}3 \\
4 \\
6\end{array}$ & 33,89 \\
\hline
\end{tabular}

Ama-hizkuntza euskalkia duten haurren kasuan, euskalkia erabiltzen dute euskara batua baino gehiago, batez beste \% 47,92an (euskara batuaren

\footnotetext{
${ }^{29}$ Jesarri eta gitxi hitzak bizkaierazkoak direla ulertu da eta taulan jasotako hitz multzo bakoitzean hitz bat barik bi esan direnean biak zenbatu dira. Taula guztietan egin da hori.

${ }^{30}$ Arin hitza euskalkiari gehiago hurbiltzen zaiola ulertu da kasu guztietan.
} 
Ipuin-moldaketa herri-hizkerara egokitzeko eta modu esanguratsuan...

erabilera batez beste $\% 41,07 \mathrm{koa}$ da). Gainera, euskalkiaren erabilera ere hazi egin da \% 39,74tik \% 47,92ra, batez beste. Adierazgarria da hiruren kasuan ez dakizkiten hitzen kopurua jaitsi egin dela nabarmen (\% 18,16tik $\%$ 11,01era, batez beste), euskaraz (batuaz zein euskalkian) esaten dakiten hitz kopuruaren mesedetan. Beraz, bete dira $\mathrm{H}_{1}$ eta $\mathrm{H}_{2.2}$ hipotesiak.

Ama-hizkuntza euskara batua duten haurren kasuan, hitz gehiago esaten dituzte bai euskalkian (batez bestean \% 32,48tik \% 48,89era) eta baita euskara batuan ere (batez bestean \% 31,62tik \% 35ra). Beraz, euskararen erabilera hazi egin da, bereziki euskalkiarena. Hau da, bete dira $\mathrm{H}_{1}, \mathrm{H}_{2.4}$ hipotesiak.

Ama-hizkuntzatzat gaztelania duten haurren kasuan, jarduera honetan euskara batua erabili dute portzentaje handiagoan (batez bestean $\%$ 30,56an, euskalkia \% 23,33an erabiltzen den artean), nahiz eta euskalkiaren erabilera modu leunean handitu den (bataz bestean \% 13,89tik $\%$ 23,33ra). Ez dakizkiten hitzen kopuruari dagokionez, eurak dira gutxien dakizkitenak, baina ipuina kontatu ostean nabarmen jaitsi da horren kopurua (batez bestean \% 52,78tik \% 33,89ra). Maileguak ere gehien erabiltzen dituzte haur hauek eta horren erabilera ez da askorik jaitsi (batez bestean $\%$ 13,89tik \% 12,22ra). Beraz, bete dira $\mathrm{H}_{1}, \mathrm{H}_{6}$ hipotesiak, bizkaieraren erabilera hazi egin da eta.

\section{ONDORIOAK}

Lan honetan ondorioztatu da Martin Txiki ipuina batueratik bizkaierara moldatzea (zehazki Mungialdeko herri-hizkerara) eta egokitzapen hori eskola batean praktikan jartzea erabilgarria dela ikasleen euskalkiaren erabilera eta barneratzea neurtzeko. Horrez gain, lan hau egiteko sortu diren baliabide guztiak irakasleen eskura jarri dira, hala nola batuerazko eta bizkaierazko kontakizunaren bideoak $^{31}$ eta horiek prestatzeko erabili diren markak (Beaskoetxea, 2018).

Ipuinaren irakurketa esanguratsuak eta hori garatzeko esku-hartzeak haurren euskarazko hizkuntza- eta komunikazio-gaitasunak garatzen lagundu die, jaso ditugun emaitzen arabera; izan ere, euren ama-hizkuntza edozein dela ere $\left(\mathrm{H}_{1}\right.$ eta $\mathrm{H}_{2}$ hipotesiak) haurrek lehenago ezagutzen ez zituzten bizkaierazko hitzak erabili dituzte bukaerako esku-hartzeetan. Baina eragina ezberdina izan da haurren ama-hizkuntza kontuan izanda. Euskalkidun haurren kasuan, euskalkia erabili dute hasieratik eta egitura berriak ikasi dituzte, esaterako udagoiena edo asau bezalako hitzak $\left(\mathrm{H}_{2.1}\right.$ eta $\mathrm{H}_{2.2}$ ). Ama-hizkuntza euskara batua duten haurren kasuan, euskalkiak berezko dituen hitz eta egiturak erabiltzea ez zen aurreikusi $\left(\mathrm{H}_{2.3}\right.$ hipote-

31 Bideoen esteka: https://addi.ehu.es/handle/10810/31766 . 
sia ez da bete), baina euskalkian irakurritako bertsioak eragin handia izan du euren euskalkiaren jarioan $\left(\mathrm{H}_{2.4}\right)$. Azkenik, ama-hizkuntza gaztelania duten haurren kasuan, zailtasunak izan dituzte irudietan ageri diren kontzeptu eta jarduerak izendatzeko eta maileguak erabili dituzte; hala ere, ipuina irakurri aurretik euskalkiak berezko dituen zenbait egitura hein askoz txikiagoan erabili dituzte euskalkidunek baino, besteak beste jesarri eta motza hitzekin eta soziatiboaren deklinabide kasuetan $(-\mathrm{gaz})\left(\mathrm{H}_{2.5} \mathrm{hi}-\right.$ potesia ez da bete) eta erabilera horiek areagotu egin dira gerora $\left(\mathrm{H}_{2.6}\right)$. Lanaren mugei dagokienez, hasteko, jarduerak egiteko erabili diren irudietan ageri diren kontzeptuetako batzuk, batez ere nozio espazialei dagozkienak (urrun adibidez) edo herria eta antzeko kontzeptuak ez dira argiak izan haur horien garapen mailarako, eta horrek emaitzetan eragin ahal izan du, ez direlako gai izan horiek izendatzeko. Gainera, ikasgelak eta haurrek eskaintzen zuten aukera oso mugatua izan da; izan ere, batez ere ez da egon ama-hizkuntza batua eta gaztelania dutenen artean hitz asko egiten duen haurrik, eta horrek emaitzak bideratu ditu, ez baitute benetako hizkuntza- eta komunikazio-gaitasunak baloratu ahal izateko hitz nahikorik egin, batez ere umeak askatasun handiagoz komunika zitezkeen jardueretan (3.3.2. azpiatalean aipatutako ipuinaren sekuentziari buruzko hipotesiak sortzeko jarduera eta 3.3.5 azpiatalean aipatutako ipuinaren amaiera asmatzeko jarduera).

Muga horiek beharrezko egiten dute etorkizunean esku-hartze eta ikerketa hau beste ikastetxe batzuetako taldeekin egitea. Horren helburua litzateke lortutako emaitzetan herri, ikastetxe eta ikastalde bakoitzean dagoen hizkuntza-errealitateak duen eragina zehaztea eta, azken finean, euskalkiaren erabilerak norbere komunikazio-gaitasunaren garapenean eta nortasunean duen garrantzia ondo neurtzea. Izan ere, besteak beste, Haur Hezkuntzako curriculumak zehazten du euskalkiarekiko interesa pizteko eta hori begirunez tratatzeko beharra, komunikazio-gaitasunaren garapenean duen papera nabarmenduz. Horrela gauzak, uste dugu hezkuntzari ere badagokiola euskalkiaren lanketa sustatzea garapen hori errazteko.

\section{ERREFERENTZIAK}

237/2015 Dekretua, abenduaren 22koa, Haur Hezkuntzako curriculuma zehaztu eta Euskal Autonomia Erkidegoan ezartzekoa.

Aizpurua, L., Beaskoetxea, U., Karrillo, J. eta Iruskieta, M. (2018). Ipuinetako pertsonaiak ezaugarritzeko komunikazio estrategiak: irakaslearentzako gida xume ulerterraza. UZTARO 107, 37-51.

Amestoy, K. eta Martinez B. (1992). Behin bazen. Donostia: Elkar.

Arejita, A. (2002). Bizkai euskeraren jarraibide liburua. Lehenengo pausuak. Bilbo: Labayru Ikastegia.

Arejita, A. (2005). Bizkai euskeraren jarraibide liburua. Bigarren pausuak. Bilbo: Labayru Ikastegia. 
Ipuin-moldaketa herri-hizkerara egokitzeko eta modu esanguratsuan...

Aurrekoetxea, G., Gaminde, I. Gandarias, L. eta Iglesias, A. (2015). Euskararen azentuera: hizkera tradizionaletatik euskara estandarrera. Eridenen du zerzaz kontenta. Sailkideen omenaldia Henrike Knörr irakasleari (1947-2008). UPV/EHUren Argitalpen Zerbitzua, 71-95.

Beaskoetxea, U. (2018). Ipuinaren moldaketa bizkaierara eta bere erabilera ahozko komunikazioa lantzeko Haur Hezkuntzan (Gradu Amaierako Lana). UPV/EHU, Leioa.

Boersma, P. (2002). Praat, a system for doing phonetics by computer. Glot international, 5 .

Díaz, G. (2016). El profesor de lenguas/IX: Competencia metodológica para la enseñanza y el aprendizaje-Principales tendencias metodológicas, enfoques y métodos contemporáneos. EHUko Udako Ikastaroak.

Canale, M. (1983). From communicative competence to communicative language pedagogy. J.C. Richards eta R.W. Schmidt (ed.). Language and Communication. Longman. New York.

Crystal, D. (2003). English as a Global Language. Cambridge: Cambridge University Press.

Elordieta, G. (2008). An overview of theories of the syntax-phonology interface. Anuario del Seminario de Filología Vasca «Julio Urquijo», 42(1), 209-286.

Elordui, A. eta Maia, J. (2002). Eskola eta dialektoak: irakaskuntzan gertatzen diren arazoak eta irtenbideak. Revista Psicodidáctica, 13, 105-116.

Etxebarria, A. eta Garay, U (2013). Komunikazio-gaitasuna: Lehen Hezkuntzako irakaslegaiak trebatzen. UPV/EHUko ikasmaterialen sare-argitalpenak. 201810-10 hartuta, hemendik: https://ikasmaterialak.ehu.eus/hezkuntza/euskarabatua-eta-euskalkiak-eskolan

Gaminde, I. (2002). Bizkaiko euskararen ezaugarri fonologiko batzuen inguruan. Euskalingua, 1, 4-14.

Garate, G. (1996). Bizkaiera eta Gipuzkera. Jakin, 92, 89-103.

García, J.D., Rigo, E. eta Jiménez, R. (2017). Multimedia Learning-a eta bigarren hizkuntzen ikaskuntza (I): teoria. e-Hizpide 90, 1-10.

García-Arriola, E.A. eta Iruskieta, M. (2016). Intentziozko irakurketa ozena: lehen urratsak. Tantak, 28(2), 85-110.

González-Such, J., Jornet, J.M eta Bakieva, M. (2013). Consideraciones metodológicas sobre la evaluación de la competencia oral en L2. Revista Electrónica de Investigación Educativa, 15(3), 1-20.

Jaurlaritza, E. (2008). Oinarrizko gaitasunak EAEko Hezkuntza Sisteman. 201809-27an hartuta, hemendik: http://www.euskadi.eus/contenidos/informacion/dig_publicaciones_innovacion/eu_curricul/adjuntos/14_curriculum_ competencias_300/300002e_Pub_BN_Competencias_Basicas_e.pdf

Maia, J. (2001). Estandarra eta dialektoak nola ulertu eta tratatu irakaskuntzan. Revista Psicodidáctica, 11-12, 239-254.

Maia, J. eta Larrea, K. (2008). Euskara batua eta euskalkiak Haur Hezkuntzan eta Lehen Hezkuntzan. UPV/EHUko ikasmaterialen sare-argitalpenak. 201710-28 hartuta, hemendik: https://ikasmaterialak.ehu.eus/hezkuntza/euskarabatua-eta-euskalkiak-eskolan

Mungiako Ikastetxeak (2012). Mungialdeko berbak. Mungia: Mungiako Udala.2017-10-28an hartuta, hemendik: http://www.mungia.org/ documents/10965/b435453d-9b5f-47f3-85a8-a21793d77a97 
Mungiako Udala eta Emun Zerbitzuak (2017). Euskara Foroak: Euskararen Plan Estrategikoa 2018-2022. 2018-01-14an hartuta, hemendik: http://www.mungia.eus/documents/10965/2ac3ac3b-bc84-4f60-8cdf-a5c5bb3aa635

Murua, M. (2010). Martin Txiki eta Basajaunak. Donostia: Elkar.

Quinto, B. (2005). Los talleres en educación infantil. Espacios de crecimiento. Barcelona: Graó.

Sánchez-Cano, M. (2001). Las estrategias educativas de iteracción verbal en el contexto educativo, in Aprendiendo a hablar con ayuda. Lleida: Milenio.

Segura, A. (2016). Euskaraz irakurtzen ikasi, irakurriz euskara ikasteko. Hizpide: euskalduntze-alfabetatzearen aldizkaria, 34(89), 4

Segura, M. (2005). El ambiente y la disciplina escolar desde el conductismo y el constructivismo. Actualidades Investigativas en Educación, 5, 1-18.

Spielmann, G. (2013). La compétence communicative les situations d'utilisation. Les essentiels. Apprendre et enseígner. 2018-02-25an hartuta, hemendik: http://faculty.georgetown.edu/spielmag/docs/FLE/competence.htm\#haut

Zuazo, K. eta Goiti, U. (2017). Uribe Kosta, Txorierri eta Mungialdeko Euskara. Bilbo: Euskal Herriko Unibertsitatea. 